Article

\title{
Towards the Development of Perennial Barley for Cold Temperate Climates-Evaluation of Wild Barley Relatives as Genetic Resources
}

\author{
Anna Westerbergh * (D), Estelle Lerceteau-Köhler, Mohammad Sameri, Girma Bedada \\ and Per-Olof Lundquist \\ Department of Plant Biology, Uppsala BioCenter, Linnean Centre for Plant Biology in Uppsala, Swedish \\ University of Agricultural Sciences, SE-75007 Uppsala, Sweden; Estelle.Lerceteau-Kohler@slu.se (E.L.-K.); \\ Mohammad.Sameri@slu.se (M.S.); Girma.Bedada@slu.se (G.B.); Per-Olof.Lundquist@slu.se (P.-O.L.) \\ * Correspondence: Anna.Westerbergh@slu.se; Tel.: +46-1867-3340
}

Received: 6 April 2018; Accepted: 8 June 2018; Published: 12 June 2018

\begin{abstract}
Perennial cereal crops could limit the negative impacts of agriculture on the environment and climate change. In cold temperate climates, perennial plants must be adapted to seasonal changes and abiotic stresses, such as frost, to be able to regrow for several years. Wild crop relatives that are perennials and already adapted to cold temperate climates may provide genetic resources for breeding new perennial cereal grain crops. Barley (Hordeum vulgare) is one of the most important cereals in northern agricultural areas, and its related perennial species may be good candidates for the development of perennial cereals. We evaluated a diverse set of 17 wild perennial Hordeum species represented by 67 accessions in field conditions with a cold winter climate and long days during summer in Central Sweden (latitude $60^{\circ} \mathrm{N}$ ). Six species (H. brevisubulatum, H. bulbosum, H. fuegianum, H. jubatum, H. lechleri and H. secalinum) showed regrowth and formation of spikes for four seasons. The most distant perennial relative of barley, H. stenostachys, showed weak regrowth. H. bulbosum, the closest perennial barley relative, had a large number of accessions with wide geographic origins that showed good regrowth. Together with its storage bulbs and its cross-compatibility with barley, this makes $H$. bulbosum an important genetic resource for the development of perennial Hordeum grains using either the domestication or the wide-hybridization strategy.
\end{abstract}

Keywords: barley; genetic resource; Hordeum bulbosum; perennial cereal grain; seasonal growth; wild relatives

\section{Introduction}

Perennial grasses play major roles in temperate ecosystems and ley cultivation. With their deep and extensive root systems and earlier and extended growth period during the vegetation season they can provide several benefits over annual grasses with regard to their impact on the environment and climate. The perennial growth habit is associated with reduced soil erosion, more efficient use of mineral nutrients, higher soil quality and carbon sequestration [1-4]. Cropping systems that include perennial cereals may, therefore, offer one of several solutions to mitigate ongoing climate change and improve food security $[5,6]$. To meet demands on food security and resilience against climate change, a diversity of perennial cereal crops need to be developed.

Perennial cereal crops that are relatives of sorghum [7], rice [8], and the wheat-relative intermediate wheatgrass (Thinopyrum intermedium) [9] are under rapid development for sub-tropic and mild temperate regions. For cold temperate climates, the development of perennial cereals is at an earlier stage, and intermediate wheatgrass and rye-relatives [10] are ongoing candidates. In cold climates, perennial plants should be adapted to the seasonal changes and stressful conditions caused by 
frost temperatures to survive for many years. To manage this, they must recognize and respond to the climate and photoperiod signals that trigger dormancy and frost tolerance. Being perennial is a complex trait, and essentially means to maintain continuous vegetative growth and, for a perennial seed-producing grass, also reproductive growth, during several seasons under the local conditions. This complex trait suggests that a high number of genes are required. Making use of wild crop relatives that are perennials and already adapted to cold temperate climates may therefore be fruitful in the breeding of perennial cereals for cold climates. By applying the domestication strategy-that is, repeated selection and crossing of plants with the most desirable traits within a perennial species-harvest yield and quality can be improved along with typical domestication traits such as resistance to shattering and uniform ripening $[9,11]$.

When selecting the perennial candidate species, it is also important to consider the cross-compatibility between the wild perennial species and other previously domesticated annual cereal crops for the production of fertile wide-hybrid offspring [12]. The wide-hybridization strategy, which uses crosses and backcrosses between parents of two different species, might allow for introgression of the perennial growth habit from a perennial species into an already existing cereal genetic background. Whereas the domestication strategy takes advantage of the perenniality already inherited in the candidate species, the wide-hybridization strategy makes use of advances already made in crop qualities in the annual parental species. Regardless of the breeding strategy, the result is likely to be a new form of crop both from the cultivation perspective and in the quality of grain used for food and feed.

For agricultural areas in cold temperate climates, perennial relatives to barley (Hordeum vulgare) may be relevant candidates for the development of perennial cereals. Barley is one of the most important cereals in the most northern agricultural areas. Also, barley and its wild relatives in the genus Hordeum are widespread among various climates in the world and can provide useful genetic resources for breeding. In Hordeum, there are about 33 wild species of which 24 species are perennials [13]. Perennial Hordeum species have a wide geographic distribution and grow in perennial grass ecosystems at different altitudes, climates and ecological zones in Asia, Africa, America, and Europe, with the highest number of species found in South America [14,15]. While most Hordeum species have a narrow geographic distribution, some species, such as H. bulbosum, do not. H. bulbosum is the closest perennial relative to cultivated barley, and produces fertile offspring with barley [16]. H. bulbosum has been used as a genetic resource in barley breeding for improvement of resistance against virus and fungal pathogens [17-19]. Wide-hybridization between barley and other perennial Hordeum species have been less successful [16]. Among the genetically most distant perennial relatives to barley are H. stenostachys and H. erectifolium $[13,20]$.

There is a diploid form of H. bulbosum, like barley, but also a tetraploid form [21]. The diploid and tetraploid forms are not morphologically distinct and are not described as separate taxa. Also, among two other perennial Hordeum species, H. brachyantherum and H. brevisubulatum, the ploidy levels have been reported to vary within the species showing diploid, tetraploid and hexaploid forms [22]. However, most of the Hordeum species, including the perennials, have a single ploidy level as either diploids, tetraploids or hexaploids.

H. bulbosum differs from other Hordeum species by its ability to form bulb structures at the base of the tillers. These bulbs function as storage organs of carbohydrates and nutrients between growing seasons. Buds below the bulbs give rise to tillers that result in rapid emergence under favorable conditions. Other perennial Hordeum species such as H. brevisubulatum and H. guatemalense have been described to form rhizomes important for vegetative propagation and regrowth [14,22].

Development of perennial barley-more broadly and properly described as perennial cereal grain crops in the genus Hordeum - has not received much attention and has not previously been presented. The extensive adaptability of perennial Hordeum species to various climates and ecological zones makes them potential genetic resources for development of perennial Hordeum grains for cultivation in Sweden and Northern Europe as well as other cold temperate regions. 
This work aimed to initiate the development of perennial Hordeum grains, hereafter referred to as perennial barley. We have therefore evaluated the potential of a diverse set of accessions of wild perennial relatives of barley to survive and regrow for several years under cold temperate climate conditions for future applications as genetic resources.

\section{Material and Methods}

\subsection{Plant Material}

Of the 24 perennial Hordeum species, we screened 17 species represented by 67 accessions (Table S1) for their growth and survival in field conditions. Four wild annual Hordeum species and three winter barley cultivars Anisette, Matros and Talisman were also included in the trial. The seeds were provided by several genebanks: Nordic Genetic Resource Centre (NordGen), Alnarp, Sweden; Leibniz-Institut Für Pflanzengenetik und Kulturpflanzenforschung (IPK), Gatersleben, Germany; National Germplasm Resources Laboratory, United States Department of Agriculture (USDA), Beltsville, MD, USA; and the company Lantmännen SW Seed AB, Svalöv, Sweden. The accessions originate from China in the east to Chile and Canada in the west. Most of the H. bulbosum accessions are from Western and Central Asia, while most of the accessions of the other Hordeum species have a South American origin. For H. bulbosum and H. stenostachys, 29 and nine accessions were used, respectively, and for the remaining species, one to three accessions were studied.

\subsection{Pre-Cultivation in Climate Chamber and Greenhouse, and Trait Evaluation in Field}

Fifty accessions of the 17 perennial Hordeum species were planted as two-year-old adult plants in the field (Table 1). These plants had large root systems at planting that ensured good establishment and growth in the first season, which allowed evaluation of survival and regrowth ability in the following years. To also evaluate regrowth of plants planted at earlier development stages, young plants at booting stage of six of the 17 perennial species were planted in the field. In addition, three of these six perennial species were seeded directly in the field. The two-year-old plants, the young plants and the seed for all species were planted in the field in May 2013. Prior to the planting, both the two-year old adult plants and the young plants were pre-cultivated in a climate chamber.

Two-year-old adult plants: In early spring 2011, seedlings derived from the 17 perennial species were cultivated in pots with a low nutrient commercial soil potting mix (S-jord, Hasselfors Garden, Örebro, Sweden) in a climate chamber (4.6 square meter, $2.4 \mathrm{~m}$ high; model BDW50, Conviron, Winnipeg, MB, Canada) at the Phytotron Plant Cultivation Facility, Uppsala BioCenter, SLU Uppsala, Sweden. After germination, the plants were cultivated for eight weeks in the climate chamber with a day/night cycle of $22 / 18^{\circ} \mathrm{C}$ and $16 / 8 \mathrm{~h}$ light/dark period with a photosynthetic active radiation of $300 \mu \mathrm{mol} \mathrm{m} \mathrm{m}^{-2} \mathrm{~s}^{-1}$. The plants were then given a vernalization treatment for six weeks at $4{ }^{\circ} \mathrm{C}$ under an $8 \mathrm{~h}$ photoperiod at $100 \mu \mathrm{mol} \mathrm{m} \mathrm{s} \mathrm{s}^{-1}$, to induce flowering. After vernalization, the plants were maintained in the climate chamber for two years. Before planting in the field, the plants were acclimatized for two weeks in a greenhouse at 22 to $25^{\circ} \mathrm{C}$ with a $16 / 8 \mathrm{~h}$ light/dark period with supplementary light from metal halogen lamps. Morphologies of spikes, root systems, and bulbs were observed. For comparison, five accessions from three annual Hordeum species were also vernalized as seedlings and cultivated in climate chamber as above until they reached flowering stage, followed by two weeks in the greenhouse until planted in the field.

Young plants: Seedlings derived from six of the 17 perennial species and of three annual Hordeum species were also pre-cultivated in the climate chamber in early spring 2013 as described above. Three of these six perennial species were also given the vernalization treatment as above before planting in the field.

The plants and seed were planted in clay soil in a farmer's field north of Uppsala, Central Sweden $\left(60^{\circ} 00^{\prime} \mathrm{N}, 17^{\circ} 42^{\prime} \mathrm{E}\right)$. The field was located at an organic farm, and a low level of animal manure fertilizer was added. Manual weeding was carried out, and no pesticides or herbicides were applied. Climate data for the cultivation period during 2013-2016 is presented in Figure S1. 
Table 1. Regrowth of wild Hordeum species and accessions established in 2013 in a farmer's field in Uppsala, Sweden (latitude $60^{\circ} \mathrm{N}$ ), located in a cold temperate climate region. The plants were evaluated during three growing seasons.

\begin{tabular}{|c|c|c|c|c|c|c|c|c|c|c|c|}
\hline \multirow[t]{2}{*}{$\begin{array}{l}\text { Plant Material/ } \\
\text { Species }\end{array}$} & \multirow[t]{2}{*}{$\begin{array}{l}\text { Ploidy } \\
\text { Level }\end{array}$} & \multirow[t]{2}{*}{$\begin{array}{l}\text { Growth } \\
\text { Habit }^{\text {a }}\end{array}$} & \multirow[t]{2}{*}{$\begin{array}{l}\text { Accession } \\
\text { ID }^{\mathbf{b}}\end{array}$} & \multirow[t]{2}{*}{$\begin{array}{c}\text { No. of Accessions } \\
\text { per Species }\end{array}$} & \multirow[t]{2}{*}{$\begin{array}{l}\text { Mean no. of Plants } \\
\text { per Accession }\end{array}$} & \multicolumn{6}{|c|}{$\begin{array}{l}\text { No. of Accessions and ID with Regrowth } \\
\text { (no. of Accessions Evaluated) }{ }^{\mathrm{d}}\end{array}$} \\
\hline & & & & & & Year & ID & Year & ID & Year & ID \\
\hline & & & & & & 2014 & & 2015 & & 2016 & \\
\hline \multicolumn{12}{|c|}{ Two-year-old plants } \\
\hline H. bogdanii & $2 x$ & $\mathrm{P}$ & 1 & 1 & 2 & $1(1)$ & 1 & $1(1)$ & 1 & - & \\
\hline H. brachyantherum & $4 \mathrm{x}$ & $\mathrm{P}$ & 2,3 & 2 & 2 & $2(2)$ & 2,3 & $1(2)$ & 3 & - & \\
\hline H. brevisubulatum & $4 \mathrm{x}$ & $\mathrm{P}$ & 4 & 1 & 2 & $1(1)$ & 4 & $1(1)$ & 4 & $1(1)$ & 4 \\
\hline H. bulbosum & $4 \mathrm{x}$ & $\mathrm{P}$ & $5-27$ & 23 & 1.1 & $23(23)$ & $5-27$ & $20(20)$ & $5-10,12-19,22-27$ & $8(8)$ & $5,12,15-17,19,22,24$ \\
\hline H. capense & $4 \mathrm{x}$ & $\mathrm{P}$ & 34 & 1 & 2 & $1(1)$ & 34 & $0(1)$ & & $0(1)$ & \\
\hline H. chilense & $2 x$ & $\mathrm{P}$ & 35,36 & 2 & 2 & $2(2)$ & 35,36 & $2(2)$ & 35,36 & - & \\
\hline H. comosum & $2 x$ & $\mathrm{P}$ & 38 & 1 & 2 & $1(1)$ & 38 & $1(1)$ & 38 & - & \\
\hline H. cordobense & $2 x$ & $\mathrm{P}$ & 39 & 1 & 2 & $1(1)$ & 39 & $0(1)$ & & $0(1)$ & \\
\hline H. depressum & $4 \mathrm{x}$ & A & 40 & 1 & 2 & $0(1)$ & & $0(1)$ & & $0(1)$ & \\
\hline H. erectifolium & $2 x$ & $\mathrm{P}$ & 41 & 1 & 2 & $1(1)$ & 41 & $0(1)$ & & $0(1)$ & \\
\hline H. euclaston & $2 x$ & A & 42 & 1 & 1 & $0(1)$ & & $0(1)$ & & $0(1)$ & \\
\hline H. fuegianum & $4 \mathrm{x}$ & $\mathrm{P}$ & 44 & 1 & 2 & $1(1)$ & 44 & $1(1)$ & 44 & $1(1)$ & 44 \\
\hline H. intercedens & $2 x$ & A & $45-47$ & 3 & 1.7 & $0(3)$ & & $0(3)$ & & $0(3)$ & \\
\hline H. jubatum & $4 \mathrm{x}$ & $\mathrm{P}$ & 48,49 & 2 & 2 & $2(2)$ & 48,49 & $2(2)$ & 48,49 & $2(2)$ & 48,49 \\
\hline H. lechleri & $6 x$ & $\mathrm{P}$ & 50 & 1 & 2 & $1(1)$ & 50 & $1(1)$ & 50 & $1(1)$ & 50 \\
\hline H. muticum & $2 x$ & $\mathrm{P}$ & 51 & 1 & 1 & $0(1)$ & & $0(1)$ & & $0(1)$ & \\
\hline H. patagonicum & $2 x$ & $\mathrm{P}$ & 53 & 1 & 2 & $1(1)$ & 53 & $1(1)$ & 53 & - & \\
\hline H. pubiflorum & $2 x$ & $\mathrm{P}$ & 54 & 1 & 2 & $1(1)$ & 54 & $1(1)$ & 54 & - & \\
\hline H. secalinum & $4 \mathrm{x}$ & $\mathrm{P}$ & 58 & 1 & 2 & $1(1)$ & 58 & $1(1)$ & 58 & $1(1)$ & 58 \\
\hline H. stenostachys & $2 x$ & $\mathrm{P}$ & $59-67$ & 9 & 1.7 & $7(9)$ & $59,60,62-65,67$ & $3(9)$ & $62,63,67$ & - & \\
\hline \multicolumn{12}{|c|}{ Young plants, vernalized } \\
\hline H. bulbosum & $2 x$ & $\mathrm{P}$ & 29,30 & 2 & 2.5 & $2(2)$ & 29,30 & $1(2)$ & 29 & - & \\
\hline H. bulbosum & $4 \mathrm{x}$ & $\mathrm{P}$ & $10,13,28,31-33$ & 6 & 2.7 & $6(6)$ & $10,13,28,31-33$ & $3(6)$ & $10,31,32$ & $1(1)$ & 10 \\
\hline H. chilense & $2 x$ & $\mathrm{P}$ & 37 & 1 & 3 & $1(1)$ & 37 & $0(1)$ & & $0(1)$ & \\
\hline H. euclaston & $2 x$ & A & 42,43 & 2 & 2 & $0(2)$ & & $0(2)$ & & $0(2)$ & \\
\hline H. pusillum & $2 x$ & A & $55-57$ & 3 & 2.7 & $0(3)$ & & $0(3)$ & & $0(3)$ & \\
\hline H. stenostachys & $2 x$ & $\mathrm{P}$ & $59-61$ & 3 & 2.7 & $2(3)$ & 59,60 & $1(3)$ & 59 & - & \\
\hline H. vulgare & $2 x$ & A & 68 & 1 & 2 & $0(1)$ & & $0(1)$ & & $0(1)$ & \\
\hline \multicolumn{12}{|c|}{ Young plants, not vernalized } \\
\hline H. brevisubulatum & $2 x$ & $\mathrm{P}$ & 4 & 1 & 2 & $1(1)$ & 4 & $1(1)$ & 4 & $1(1)$ & 4 \\
\hline H. muticum & $2 x$ & $\mathrm{P}$ & 52 & 1 & 2 & $1(1)$ & 52 & $0(1)$ & & $0(1)$ & \\
\hline H. pubiflorum & $2 x$ & $\mathrm{P}$ & 54 & 1 & 1 & $0(1)$ & & $0(1)$ & & $0(1)$ & \\
\hline
\end{tabular}


Table 1. Cont.

\begin{tabular}{|c|c|c|c|c|c|c|c|c|c|c|c|}
\hline \multirow[t]{2}{*}{$\begin{array}{l}\text { Plant Material/ } \\
\text { Species }\end{array}$} & \multirow[t]{2}{*}{$\begin{array}{c}\text { Ploidy } \\
\text { Level }\end{array}$} & \multirow[t]{2}{*}{$\begin{array}{l}\text { Growth } \\
\text { Habit }^{\text {a }}\end{array}$} & \multirow[t]{2}{*}{$\begin{array}{l}\text { Accession } \\
\text { ID }^{\mathrm{b}}\end{array}$} & \multirow[t]{2}{*}{$\begin{array}{l}\text { No. of Accessions } \\
\text { per Species }\end{array}$} & \multirow[t]{2}{*}{$\begin{array}{l}\text { Mean no. of Plants } \\
\text { per Accession }\end{array}$} & \multicolumn{6}{|c|}{$\begin{array}{l}\text { No. of Accessions and ID with Regrowth }{ }^{c} \\
\text { (no. of Accessions Evaluated) }{ }^{\mathrm{c}}\end{array}$} \\
\hline & & & & & & Year & ID & Year & ID & Year & ID \\
\hline & & & & & & 2014 & & 2015 & & 2016 & \\
\hline \multicolumn{12}{|l|}{ Seed } \\
\hline H. brevisubulatum & $4 \mathrm{x}$ & $\mathrm{P}$ & 4 & 1 & 1 & $1(1)$ & 4 & $1(1)$ & 4 & - & \\
\hline H. bulbosum & $4 \mathrm{x}$ & $\mathrm{P}$ & 12,22 & 2 & 1 & $2(2)$ & 12,22 & $2(2)$ & 12,22 & - & \\
\hline H. pubiflorum & $2 x$ & $\mathrm{P}$ & 54 & 1 & 1 & 0 (1) & & $0(1)$ & & $0(1)$ & \\
\hline H. vulgare & $2 x$ & A & 69,70 & 2 & 2 & $0(2)$ & & $0(2)$ & & $0(2)$ & \\
\hline
\end{tabular}

are indicated by - 
Regrowth was assessed based on the presence of new leaves originating from old plant parts in May and August 2014 (second growing season), in July 2015 (third growing season) and in August 2016 (fourth growing season). Presence of leaves was scored from 0 (no leaves) to 5 (50 or more leaves). Presence versus absence of spikes was recorded in August 2014 and in July 2015.

\subsection{Data Analysis}

To analyze and display the distribution of the perennial Hordeum species based on regrowth (leaf and spike) data from 2014 and 2015, we applied multivariate Principal Coordinate Analysis (PCoA) to a dissimilarity matrix constructed from the dataset treated as qualitative variables. To test the distribution of the two species with larger numbers of accessions (H. bulbosum and H. stenostachys) along the three first PCoA components, and residuals for each of the two species were checked for deviations from normality. As the residuals for all three components did not show normal distribution for both species, we applied the non-parametric Kruskal-Wallis test. The same test was also employed for the analysis of differences in individual traits. The statistical analyses were carried out using the software XLSTAT 2018.3 (Addinsoft, New York, NY, USA).

\section{Results}

\subsection{Diversity in Regrowth Ability}

The two-year-old plants of the perennial species and the adult plants of the annual species established well in the field 2013 (Figure 1).
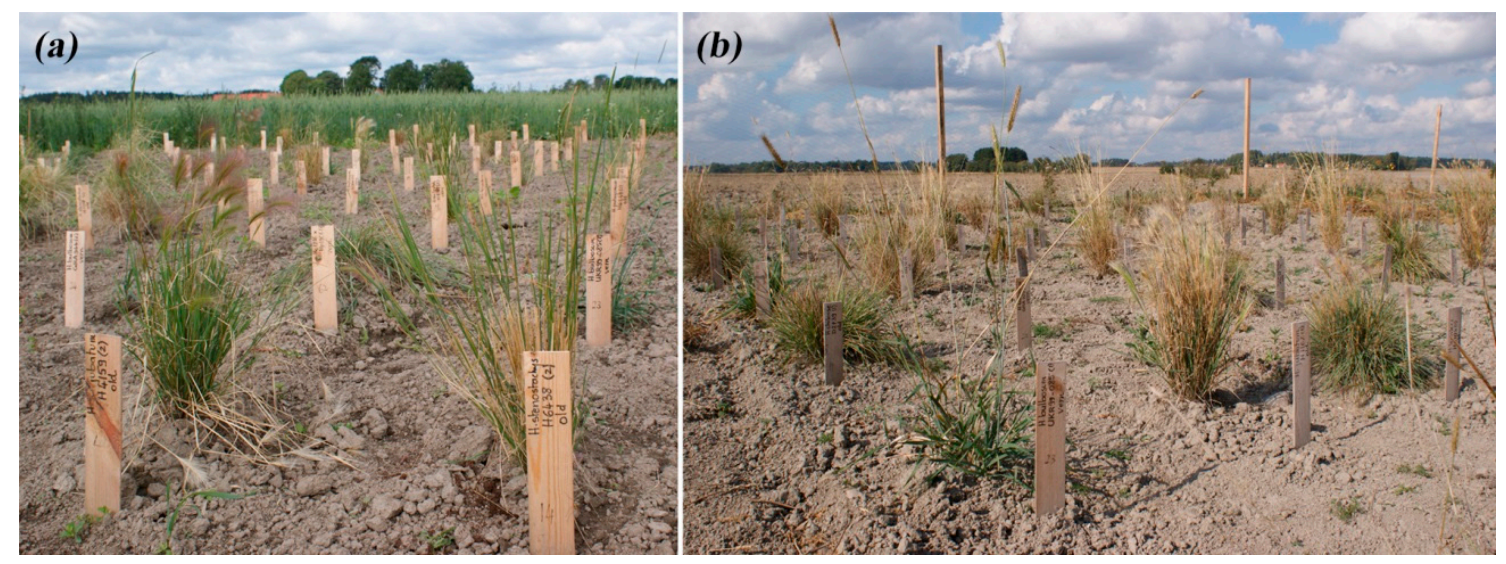

Figure 1. Field evaluation of Hordeum plant material at the field site in Uppsala, Sweden (latitude $60^{\circ} \mathrm{N}$ ). Accessions of wild Hordeum species during the first of four growing seasons in 2013: (a) in summer, showing examples of species, from left H. jubatum and H. stenostachys; (b) in fall, from left $H$. chilense, H. bulbosum, H. jubatum and H. lechleri. Photographs by Anna Westerbergh.

Accessions of all perennial species, except H. muticum (47 out of 50 accessions), showed regrowth in the spring of the second growing season (2014) following the first winter (Table 1). In total 36 accessions of 13 perennial species also survived the second winter and produced new leaves and tillers during the third season (2015). Seven species showed relatively strong regrowth in both 2014 and 2015, while six species showed weak regrowth (Table 2). 
Table 2. Regrowth ability in perennial wild Hordeum species planted in 2013 as two-year-old plants, as young plants at booting stage or as seed in a farmer's field in Uppsala, Sweden (latitude $60^{\circ} \mathrm{N}$ ), located in a cold temperate climate. Mean and standard error of presence of leaves after regrowth scored from 0 (no leaves) to 5 (50 or more leaves) and presence of spikes scored from 0 (no spikes) to 1 (presence of spikes) of plants of each species. See Table 1 for additional information.

\begin{tabular}{|c|c|c|c|c|c|c|}
\hline \multirow[t]{2}{*}{ Species } & \multicolumn{4}{|c|}{ Presence of Leaves } & \multicolumn{2}{|c|}{ Presence of Spikes } \\
\hline & May 2014 & August 2014 & July 2015 & August 2016 & August 2014 & July 2015 \\
\hline \multicolumn{7}{|c|}{ Two-year-old plants } \\
\hline H. bogdanii & $2.5 \pm 0.5$ & $3.0 \pm 0.0$ & $2.0 \pm 0.0$ & & $1.0 \pm 0.0$ & $1.0 \pm 0.0$ \\
\hline H. brachyantherum & $1.6 \pm 0.5$ & $1.8 \pm 0.5$ & $0.5 \pm 0.3$ & & $1.0 \pm 0.0$ & 0 \\
\hline H. brevisubulatum & $4.0 \pm 0.0$ & $3.5 \pm 0.5$ & $4.5 \pm 0.5$ & $2.5 \pm 0.5$ & $1.0 \pm 0.0$ & $1.0 \pm 0.0$ \\
\hline H. bulbosum & $2.9 \pm 0.2$ & $2.6 \pm 0.1$ & $1.9 \pm 0.2$ & $0.8 \pm 0.2$ & $1.0 \pm 0.0$ & $0.7 \pm 0.1$ \\
\hline H. capense & $0.8 \pm 0.2$ & $0.2 \pm 0.2$ & $\begin{array}{l}1.2 \\
0\end{array}$ & & $0.5 \pm 0.5$ & $\begin{array}{l} \pm .1 \\
0\end{array}$ \\
\hline H. chilense & $0.8 \pm 0.2$ & $1.2 \pm 0.6$ & $0.5 \pm 0.3$ & & $0.8 \pm 0.2$ & $0.2 \pm 0.2$ \\
\hline H. comosum & $1.0 \pm 1.0$ & $1.0 \pm 1.0$ & $1.0 \pm 1.0$ & & $0.5 \pm 0.5$ & $0.5 \pm 0.5$ \\
\hline H. cordobense & $0.5 \pm 0.5$ & $0.5 \pm 0.5$ & 0 & & $0.5 \pm 0.5$ & 0 \\
\hline H. erectifolium & $0.5 \pm 0.5$ & $0.5 \pm 0.5$ & 0 & & $0.5 \pm 0.5$ & 0 \\
\hline H. fuegianum & $2.5 \pm 0.5$ & $2.5 \pm 0.5$ & $3.0 \pm 0.0$ & $1.0 \pm 1.0$ & $1.0 \pm 0.0$ & $1.0 \pm 0.0$ \\
\hline H. jubatum & $1.2 \pm 0.2$ & $1.8 \pm 0.2$ & $0.9 \pm 0.1$ & $0.5 \pm 0.5$ & $0.8 \pm 0.2$ & $0.5 \pm 0.3$ \\
\hline H. lechleri & $2.5 \pm 0.5$ & $4.5 \pm 0.5$ & $3.0 \pm 0.0$ & $1.0 \pm 1.0$ & 0 & $1.0 \pm 0.0$ \\
\hline H. muticum & 0 & 0 & 0 & & 0 & 0 \\
\hline H. patagonicum & $2.5 \pm 0.5$ & $2.5 \pm 0.5$ & $0.2 \pm 0.2$ & & $1.0 \pm 0.0$ & 0 \\
\hline H. pubiflorum & $2.5 \pm 0.5$ & $2.0 \pm 1.0$ & $2.5 \pm 0.5$ & & $1.0 \pm 0.0$ & $1.0 \pm 0.0$ \\
\hline H. secalinum & $3.0 \pm 0.0$ & $3.0 \pm 0.0$ & $3.0 \pm 0.0$ & $1.5 \pm 1.5$ & $1.0 \pm 0.0$ & $0.5 \pm 0.5$ \\
\hline H. stenostachys & $0.6 \pm 0.2$ & $0.7 \pm 0.2$ & $0.3 \pm 0.1$ & & $0.5 \pm 0.1$ & 0 \\
\hline \multicolumn{7}{|c|}{ Young plants, vernalized } \\
\hline H. bulbosum (2x) & $1.5 \pm 0.3$ & $1.8 \pm 0.5$ & $0.3 \pm 0.2$ & 0 & $1.0 \pm 0.0$ & $0.0 \pm 0.0$ \\
\hline H. bulbosum (4x) & $2.4 \pm 0.1$ & $2.7 \pm 0.2$ & $1.0 \pm 0.3$ & $0.5 \pm 0.2$ & $0.9 \pm 0.1$ & $0.4 \pm 0.1$ \\
\hline H. chilense & $0.3 \pm 0.2$ & 0 & 0 & & 0 & 0 \\
\hline H. stenostachys & $0.4 \pm 0.2$ & $0.6 \pm 0.5$ & $0.2 \pm 0.1$ & & $0.2 \pm 0.2$ & $0.2 \pm 0.2$ \\
\hline \multicolumn{7}{|c|}{ Young plants, not vernalized } \\
\hline H. brevisubulatum & $2.5 \pm 0.5$ & $3.0 \pm 1.0$ & $3.0 \pm 0.0$ & $1.0 \pm 1.0$ & $1.0 \pm 0.0$ & $1.0 \pm 0.0$ \\
\hline H. muticum & $0.2 \pm 0.2$ & 0 & 0 & & 0 & 0 \\
\hline H. pubiflorum & 0 & 0 & 0 & & 0 & 0 \\
\hline \multicolumn{7}{|l|}{ Seeds } \\
\hline H. brevisubulatum & $1.0 \pm 2.0$ & $1.0 \pm 2.0$ & $1.5 \pm 2.0$ & & 0 & 0 \\
\hline H. bulbosum & $1.3 \pm 0.3$ & $0.7 \pm 0.3$ & $2.0 \pm 1.0$ & & $0.3 \pm 0.3$ & $0.3 \pm 0.3$ \\
\hline H. pubiflorum & 0 & 0 & 0 & & 0 & 0 \\
\hline
\end{tabular}

The two species with large numbers of studied accessions, H. bulbosum and H. stenostachys, showed significant differences in regrowth ability $(p<0.0001$, Kruskal-Wallis test, Figure 2a-c). Twenty of the $23 \mathrm{H}$. bulbosum accessions studied showed good regrowth (Figure 3), while only three of the nine studied accessions of $H$. stenostachys survived the second winter (Table 1). In the fourth season (2016), accessions of six of the species $H$. brevisubulatum, $H$. bulbosum, $H$. fuegianum, $H$. jubatum, $H$. lechleri and H. secalinum continued to show regrowth (Table 1). Thus, the same plants of these accessions had survived four consecutive years in the field. None of the species described as annuals survived the first winter in the field.

Spikes were formed by accessions planted as two-year-old plants in 13 of the 16 species living in 2014, and in nine of the 10 species remaining in 2015 (Table 3). Forty-two and 19 accessions formed spikes in 2014 and 2015, respectively. Almost all species with a strong regrowth in 2015 also formed spikes (Table 2). The accessions of H. bulbosum showed a significantly higher ability to form spikes than the accessions of H. stenostachys in both 2014 and 2015 ( $p<0.0001$, Kruskal-Wallis test, Figure 2d,e). 

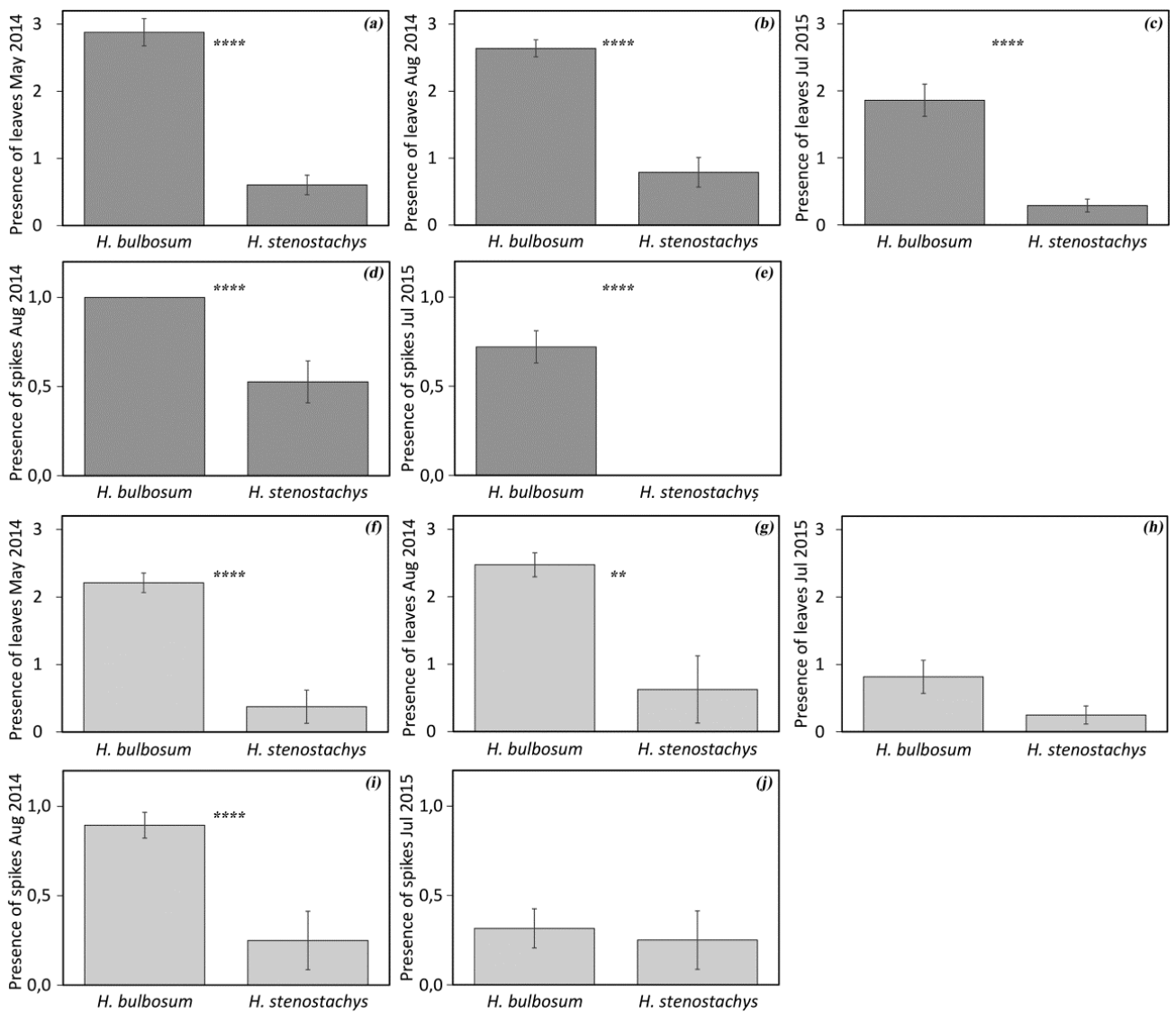

Figure 2. Presence of leaves and spikes in plants of Hordeum bulbosum and H. stenostachys evaluated in a farmer's field in Uppsala, Sweden (latitude $60^{\circ} \mathrm{N}$ ), located in a cold temperate climate region. (a-e) Plants of 23 accessions of $H$. bulbosum and nine accessions of $H$. stenostachys that were two years old at planting; (f-j) young plants of eight accessions of H. bulbosum and three accessions of $H$. stenostachys, vernalized and at booting stage at planting. Data shown are mean and standard error of presence of leaves after regrowth scored from 0 (no new leaves) to 5 (50 or more leaves) in May 2014, in August 2014 and in July 2015, and presence of spikes scored from 0 (no spikes) to 1 (presence of spikes) in August 2014 and in July 2015. (** $p<0.01,{ }^{* * * *} p<0.0001$, Kruskal-Wallis test).



Figure 3. Cont. 

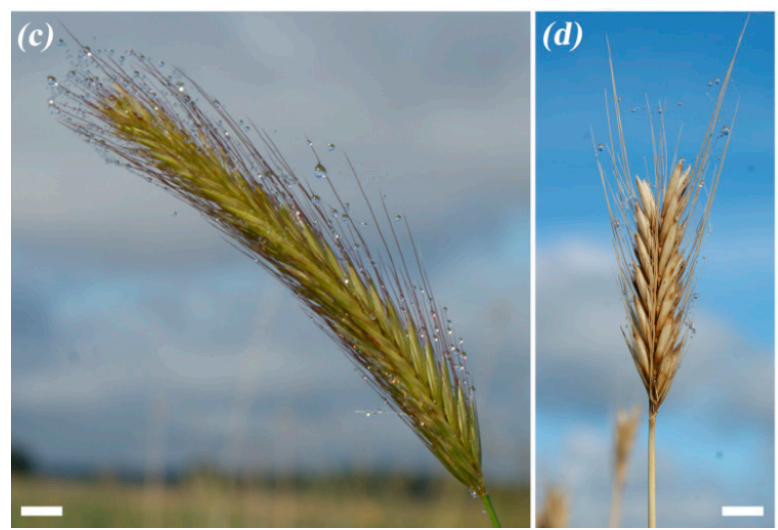

Figure 3. H. bulbosum. (a) plant during flowering in the first season in the field originating from seedling vernalized in the climate chamber before planting; (b) plant regrowing during the third season observed at head emergence stage and with a few non-intact brittle spikes from previous year; (c) intact spike before flowering; (d) brittle spike at maturity not intact at the top. Bars are $10 \mathrm{~cm}(\mathbf{a}, \mathbf{b})$ and $1 \mathrm{~cm}$ (c,d). Photographs by Anna Westerbergh (a), Girma Bedada (b) and Per-Olof Lundquist (c,d).

Table 3. Presence of spikes in wild Hordeum species and accessions established in 2013 in a farmer's field in Uppsala, Sweden (latitude $60^{\circ} \mathrm{N}$ ), located in a cold temperate climate region. The plants were evaluated during two growing seasons. See Table 1 for additional information.

\begin{tabular}{|c|c|c|c|c|c|}
\hline \multirow[t]{2}{*}{$\begin{array}{l}\text { Plant Material/ } \\
\text { Species }\end{array}$} & \multirow[t]{2}{*}{ Accession ID $^{a}$} & \multicolumn{4}{|c|}{$\begin{array}{l}\text { No. of Accessions and ID with Spikes b } \\
\text { (no. of Accessions with Regrowth) }\end{array}$} \\
\hline & & Year & ID & Year & ID \\
\hline & & 2014 & & 2015 & \\
\hline \multicolumn{6}{|l|}{ Two-year old plants } \\
\hline H. bogdanii & 1 & $1(1)$ & 1 & $1(1)$ & 1 \\
\hline H. brachyantherum & 2,3 & $2(2)$ & 2,3 & $0(1)$ & \\
\hline H. brevisubulatum & 4 & $1(1)$ & 4 & $1(1)$ & 4 \\
\hline H. bulbosum & $5-27$ & $23(23)$ & $5-27$ & $15(20)$ & $5,7,9,10,12-19,22-24$ \\
\hline H. capense & 34 & $0(1)$ & & $0(0)$ & \\
\hline H. chilense & 35,36 & $2(2)$ & 35,36 & $0(2)$ & \\
\hline H. comosum & 38 & $1(1)$ & 38 & $1(1)$ & 38 \\
\hline H. cordobense & 39 & $1(1)$ & 39 & $0(0)$ & \\
\hline H. depressum & 40 & $0(1)$ & & $0(0)$ & \\
\hline H. erectifolium & 41 & $0(1)$ & & $0(0)$ & \\
\hline H. euclaston & 42 & $0(1)$ & & $0(0)$ & \\
\hline H. fuegianum & 44 & $1(1)$ & 44 & $1(1)$ & 44 \\
\hline H. intercedens & $45-47$ & $0(3)$ & & $0(0)$ & \\
\hline H. jubatum & 48,49 & $1(2)$ & 49 & $1(2)$ & 49 \\
\hline H. lechleri & 50 & $0(1)$ & & $1(1)$ & 50 \\
\hline H. muticum & 51 & $0(0)$ & & $0(0)$ & \\
\hline H. patagonicum & 53 & $1(1)$ & 53 & $0(1)$ & \\
\hline H. pubiflorum & 54 & $1(1)$ & 54 & $1(1)$ & 54 \\
\hline H. secalinum & 58 & $1(1)$ & 58 & $1(1)$ & 58 \\
\hline H. stenostachys & $59-67$ & $6(9)$ & $59,60,62,63,65,67$ & $0(3)$ & \\
\hline \multicolumn{6}{|c|}{ Young plants, vernalized } \\
\hline H. bulbosum $(2 \mathrm{x})$ & 29,30 & $2(2)$ & 29,30 & $0(1)$ & \\
\hline H. bulbosum (4x) & $10,13,28,31-33$ & $6(6)$ & $10,13,28,31-33$ & $3(3)$ & $10,31,32$ \\
\hline H. chilense & 37 & $0(1)$ & & $0(0)$ & \\
\hline H. euclaston & 42,43 & $0(2)$ & & $0(0)$ & \\
\hline H. pusillum & $55-57$ & $0(3)$ & & $0(0)$ & \\
\hline
\end{tabular}


Table 3. Cont.

\begin{tabular}{|c|c|c|c|c|c|}
\hline \multirow[t]{2}{*}{$\begin{array}{l}\text { Plant Material/ } \\
\text { Species }\end{array}$} & \multirow[t]{2}{*}{ Accession ID $^{a}$} & \multicolumn{4}{|c|}{$\begin{array}{l}\text { No. of Accessions and ID with Spikes } \\
\text { (no. of Accessions with Regrowth) }\end{array}$} \\
\hline & & Year & ID & Year & ID \\
\hline & & 2014 & & 2015 & \\
\hline H. stenostachys & $59-61$ & $1(3)$ & 59 & $1(1)$ & 59 \\
\hline H. vulgare & 68 & $0(1)$ & & $0(0)$ & \\
\hline \multicolumn{6}{|c|}{ Young plants, not vernalized } \\
\hline H. brevisubulatum & 4 & $1(1)$ & 4 & $1(1)$ & 4 \\
\hline H. muticum & 52 & $0(1)$ & & $0(0)$ & \\
\hline H. pubiflorum & 54 & $0(1)$ & & $0(0)$ & \\
\hline \multicolumn{6}{|l|}{ Seed } \\
\hline H. brevisubulatum & 4 & $0(1)$ & & $0(1)$ & \\
\hline H. bulbosum & 12,22 & $1(2)$ & 22 & $0(2)$ & \\
\hline H. pubiflorum & 54 & $0(1)$ & & $0(0)$ & \\
\hline H. vulgare & 69,70 & $0(2)$ & & $0(0)$ & \\
\hline
\end{tabular}

${ }^{\mathrm{a}}$ see Table $\mathrm{S} 1$ for details about the accessions, ${ }^{\mathrm{b}}$ at least one plant per accession showed presence of spikes.

PCoA based on the recorded leaf regrowth and spike formation in 2014 and 2015 for all the perennial Hordeum species planted as two-year-old plants, showed that most H. bulbosum accessions were different from the accessions of H. stenostachys (Figure 4). The distribution of the two species along the first PCoA component was significantly different $(p<0.0001$, Kruskal-Wallis test). The distributions of several of the other species present as one to two accessions, for example, $H$. bogdanii, H. brevisubulatum, $H$. fuegianum, and $H$. secalinum, overlapped with the distribution of $H$. bulbosum and were not significantly different from the distribution of $H$. bulbosum ( $p>0.05$, Kruskal-Wallis test). However, compared to H. stenostachys they showed a significantly different distribution $(p<0.05$, Kruskal-Wallis test).

Vernalized young plants of the three studied perennial species and non-vernalized young plants of two of three species showed regrowth the following season (Table 1). However, H. bulbosum present as eight accessions and $\mathrm{H}$. brevisubulatum with one accession, were the only species with relatively strong regrowth (Table 2). The regrowth during the third season in 2015 was less frequent for several species, and the accession of $H$. chilense and H. muticum and some accessions of H. bulbosum and H. stenostachys did not manage to regrow. A comparison of H. bulbosum and H. stenostachys, showed that H. bulbosum had a significantly higher regrowth ability in 2014 ( $p<0.01$, Kruskal-Wallis test, Figure 2f-h), but not in 2015. Significant differences in ability to form spikes in $2014(p<0.0001$, Kruskal-Wallis test, Figure 2i,j), but not in 2015 were also found for the two species.

For species planted as seed, the two accessions of $H$. bulbosum and the accession of H. brevisubulatum survived the first winter and showed regrowth in 2014 and 2015 (Table 1). Only one of the H. bulbosum accession formed spikes in 2014, while none of the accessions planted as seed flowered in 2015 (Table 3).

The proportion (approx. 90\%) of perennial accessions that showed regrowth in 2014 was similar for plants planted in the field as two-year-old adult plants and as young plants (Table 1). However, in 2015, the proportion of the accessions that showed regrowth was higher for plants planted as two-year-old plants (77\% versus $46 \%$ ). The ability to form spikes was higher in the two-year-old plants both in 2014 and in 2015 (Table 3). 


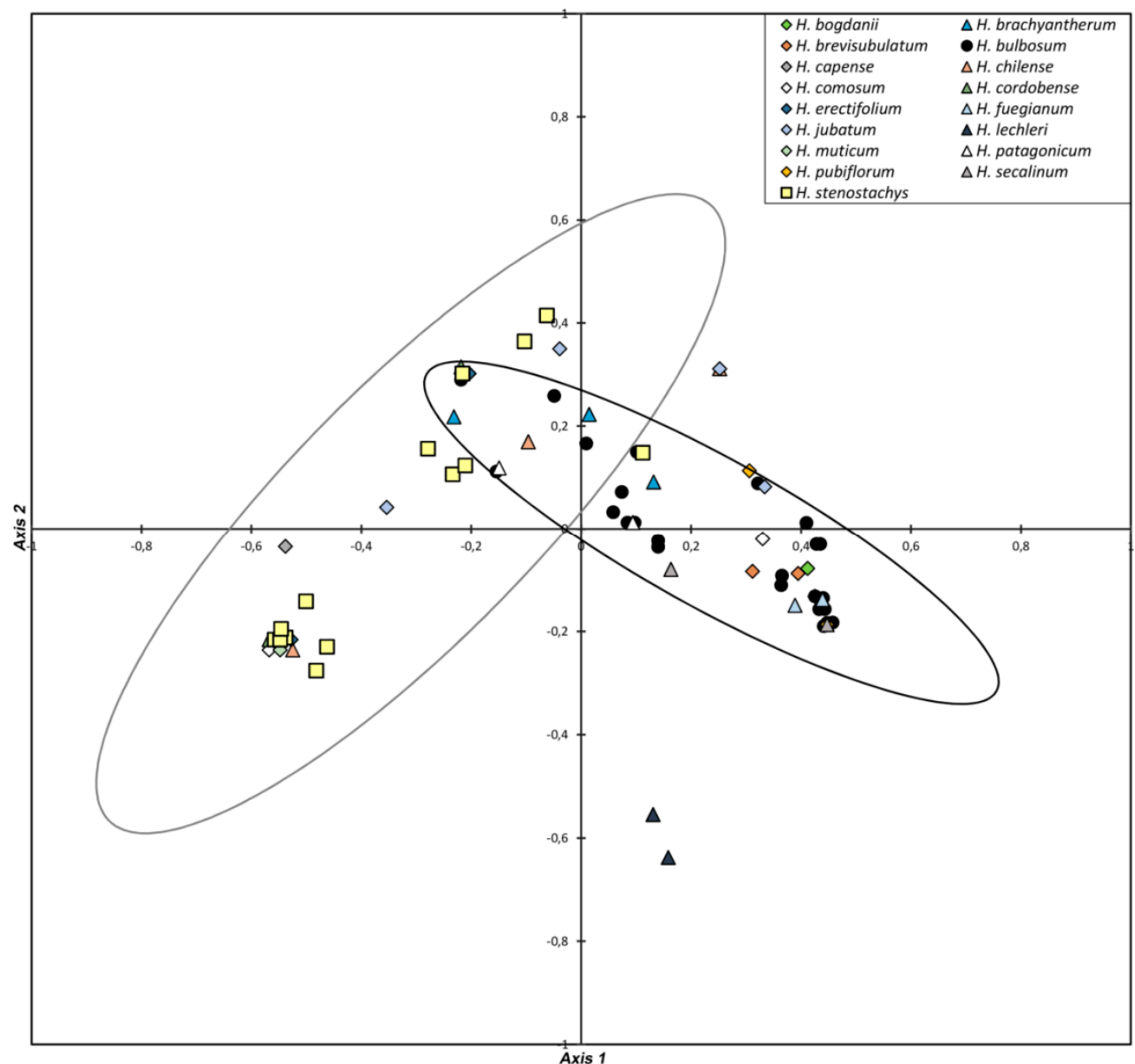

Figure 4. Score plot of Principal Coordinate Analysis based on plant regrowth traits (presence of leaves and spikes) of field-cultivated wild perennial Hordeum species in May and August 2014 and in July 2015. The first component explains $40 \%$ of the variation and the second component explains $16 \%$ of the variation. Ellipses indicate $95 \%$ confidence intervals of $H$. bulbosum and H. stenostachys. The accessions of $H$. bulbosum and H. stenostachys were significantly different based on the distribution along the first component ( $p<0.0001$, Kruskal-Wallis test).

\subsection{Diversity in Spike Morphology and Storage Bulbs}

Substantial variation in spike morphology, for example, spike and awn length, was observed among (Figure 5a) and within the perennial Hordeum species, as exemplified by H. bulbosum (Figure 5b). H. bulbosum spikes were brittle at maturity; the spikelets gradually shattered from the top of the spike (Figure 3c,d).

Even though the Hordeum species like all grasses are hermaphrodites, they show different rates of outcrossing, varying from mainly inbreeding as in $H$. chilense and H. jubatum, to obligate outcrossing with self-incompatibility systems as in $H$. bulbosum and H. brevisubulatum $[14,23]$. Since obligate outcrossing species require pollination by compatible genotypes for seed production, in contrast to inbreeding species, which reproduce through self-fertilization, seed production was difficult to compare between species and was therefore not scored in the field trial. However, several of the H. bulbosum accessions produced seed during three seasons (2014 to and 2016, Figure 3d), showing that cross-pollination occurred between the large number of $\mathrm{H}$. bulbosum accessions planted in the field.

Presence of bulbs at the base of tillers on H. bulbosum was confirmed and was not observed for the other perennial Hordeum species (Figure $5 \mathrm{c}-\mathrm{f}$ ). Diversity in bulb shape among H. bulbosum accessions was found as well as the number of bulbs per tiller (Figure 5e,f). Some H. bulbosum accessions formed only one bulb per tiller, while others also formed more than one bulb on each tiller. 


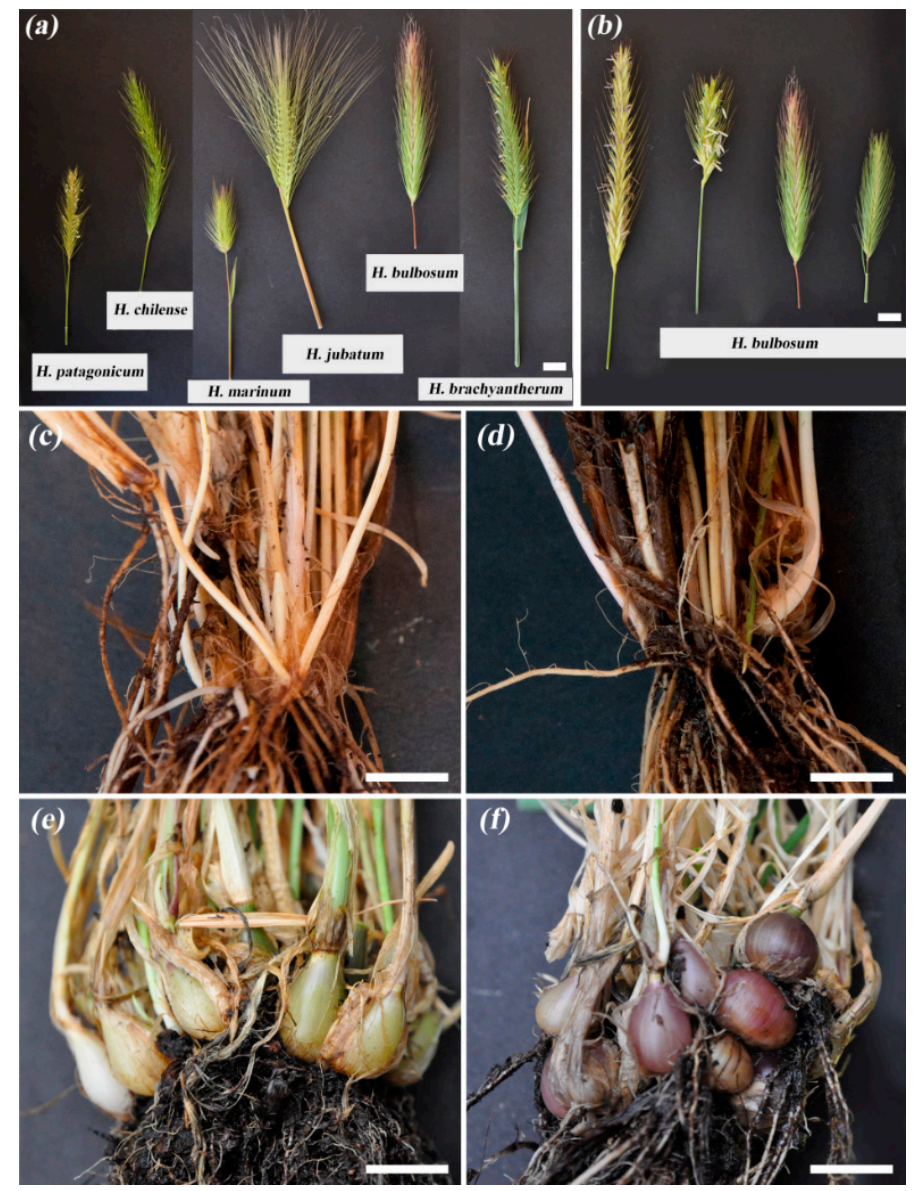

Figure 5. Examples of diversity in Hordeum. (a) Morphologies of spikes in six perennial Hordeum species; (b) in four accessions of H. bulbosum; shoot bases of (c) H. chilense; (d) H. stenostachys; (e,f) two accessions of H. bulbosum. (e) An H. bulbosum accession with one storage bulb at the base of each tiller and (f) an H. bulbosum accession with more than one bulb vertically distributed along the same tiller. Bars are $1 \mathrm{~cm}$. Photographs by Estelle Lerceteau-Köhler.

\section{Discussion}

Breeding of perennial cereal grain crops for cultivation in perennial cropping systems is one strategy to improve the impact of agriculture on the environment and climate change. Perennial cereals could also contribute to increase the resilience of agriculture to climate change and to enhance food security. The importance of agriculture across geographic regions and climate zones demands a diversity of perennial cereals with a variety of adaptations. Barley and other Hordeum species are widespread and well adapted to a wide range of habitats and could provide candidates that can fill the gap of perennial cereals in cold temperate climates. With the goal to develop perennial barley, we have as a first step evaluated a diverse group of perennial Hordeum species. This evaluation was done in field conditions during several seasons to identify candidate Hordeum species that could survive cold winters and show vegetative and reproductive regrowth during repeated seasons. This approach made it possible to narrow down the possible candidates among the range of wild perennial barley relatives and to identify accessions with favorable traits as genetic resources for further breeding.

The 17 studied perennial Hordeum species showed large diversity in the ability to regrow over seasons, where some species had good regrowth and others did not survive the first or second winter. Interestingly, accessions of the species H. brevisubulatum, H. bulbosum, H. fuegianum, H. jubatum, $H$. lechleri and $H$. secalinum survived and regrew for four seasons under the long day temperate cold climate, even though they originated from geographic areas with a climate and photoperiod at least 
partially different compared to at the evaluation site. All of these species except $H$. lechleri also formed spikes after regrowth. For H. brevisubulatum and H. bulbosum winter survival and regrowth was found in plants when planted as two-year old plants as well as young plants and seed. In PCoA based on multiple traits associated with regrowth, $H$. brevisubulatum, $H$. fuegianum, and $H$. secalinum showed overlapping distribution with the many accessions of $H$. bulbosum providing additional support for the similar performance. Interestingly, $H$. stenostachys, a species with many available accessions, and its close relatives $H$. cordobense, $H$. erectifolium and $H$. muticum clearly differed from their very distant relative, $H$. bulbosum, in their performance due to their weak regrowth ability. In addition, the four closely related Hordeum species all have a South American origin, while H. bulbosum originates from Europe and Asia [14].

A factor contributing to the good winter survival and regrowth of $H$. brevisubulatum could be its strong ability to form rhizomes [14,22]. Also, H. brevisubulatum and H. secalinum have been shown to have a high tolerance to salt stress $[24,25]$, which has similarities to frost stress with regard to dehydration, and they induce similar plant responses such as the production of osmotically active compounds [26]. Tolerance to salt was also found to be higher in tetraploid H. bulbosum compared to diploid forms [27]. The traits of H. brevisubulatum and H. secalinum and their ability for regrowth, suggest that these species, as well as the other species with similar performances to H. bulbosum, deserve further evaluation as domestication candidates or as potential donors in wide-hybrid crosses with barley.

Most $H$. bulbosum accessions in this study were tetraploids and they displayed good regrowth over several consecutive years. Also, the few diploid accessions showed regrowth. Both the tetraploid and diploid accessions produce bulbs at the base of the tillers for storage of carbohydrates, which may play an important role to support regrowth until the plant begins active photosynthesis.

Whereas most Hordeum species have a narrow distribution, H. bulbosum grows in a wide range of habitats such as dry grasslands, shrubland, dry hillsides, wet meadows and coastal sites and can also be found at abandoned fields and roadsides [14]. The diploid form occurs along the Mediterranean coast from Spain eastwards to Greece and along the North African coast to Egypt, whereas the tetraploid form is found in the regions south of the Black Sea eastwards to Afghanistan and southern Tadzjikistan. H. bulbosum with its wide geographic distribution, different ploidy forms, and adaptability to various habitats can provide potential genetic resources for perennial barley development. In fact, most of the 29 studied accessions of $H$. bulbosum showed good vegetative regrowth and ability to form spikes for several seasons, and are interesting breeding material in the development of perennial barley for cold temperate climates.

Another advantage of H. bulbosum as a candidate species compared to other wild perennial Hordeum species is the close relationship to barley seen in the high levels of conserved synteny between the barley and H. bulbosum genomes [28-30]. All the technical resources that are available for barley breeding are therefore also accessible and highly valuable for breeding towards perennial barley. These resources significantly increase the possibilities to identify genes important for agronomic and quality traits, and to apply this knowledge in perennial cereal breeding. Also, characterization of genetic diversity in H. bulbosum breeding populations is greatly facilitated by its similarities to barley and the availability of the resources.

The close genetic relationship of H. bulbosum and barley has also made it possible to obtain fertile offspring in crosses between the two species, in contrast to crosses between barley and most other perennial Hordeum species [16]. Using the wide-hybridization strategy, offspring have been made into introgression lines (ILs) carrying different $H$. bulbosum segments introgressed into a barley genetic background through backcrossing or selfing [12,31]. These ILs were developed to improve pathogen resistance in barley [12]. However, based on the good regrowth ability found in a majority of the studied accessions of H. bulbosum in a field site in Uppsala, these ILs are also interesting genetic resources for the breeding of perennial barley for cold temperate climates. We have therefore evaluated a diverse set of ILs where different parts of chromosomes of $\mathrm{H}$. bulbosum have been introgressed into barley cultivars 
in a companion paper in this issue (Westerbergh et al. 2018). Based on our findings and advantages discussed above, $H$. bulbosum is suggested to be a valuable genetic resource for the development of perennial barley using either the domestication strategy or the wide-hybridization strategy.

\section{Conclusions}

This pre-breeding study provides the first evaluation of candidate species towards the development of perennial barley. Among a large set of perennial Hordeum species, some candidates were identified, and $\mathrm{H}$. bulbosum was considered as the most promising genetic resource for future work towards a barley-related perennial crop. The continuous regrowth over several seasons in a cold temperate climate, and its close relatedness to barley that makes crosses and introgressions of genes and traits possible, as well as the immediate access to the technical resources for barley breeding, all contribute to making H. bulbosum a strong candidate.

Supplementary Materials: The following are available online at http:/ /www.mdpi.com/2071-1050/10/6/1969/s1. Table S1: Species and accessions included in the comparison of regrowth of wild Hordeum species in cold temperate climate. Figure S1: Monthly mean temperatures and precipitations at the field site in Uppsala, Sweden (latitude $\left.60^{\circ} \mathrm{N}\right)$.

Author Contributions: A.W. conceived the study and A.W., E.L.-K. and M.S. designed the study. E.L.-K. and M.S. performed the field trial. All authors contributed to the discussion of the results. A.W. and P.-O.L. analyzed the results and wrote the paper.

Funding: The Swedish Research Council for Environment, Agricultural Sciences and Spatial Planning Formas and The Lantmännen Research Foundation are gratefully acknowledged.

Acknowledgments: We thank Urban Pettersson and Per Lindén at the Phytotron Plant Cultivation Facility, Uppsala BioCenter, SLU Uppsala, Sweden, for valuable assistance. We thank Kjell and Ylva Sjelin for making fields available for the field experiments and inspiring discussions.

Conflicts of Interest: The authors declare no conflict of interest.

\section{References}

1. Crews, T.E.; Blesh, J.; Culman, S.W.; Hayes, R.C.; Jensen, E.S.; Mack, M.C.; Peoples, M.B.; Schipanski, M.E. Going where no grains have gone before: From early to mid-succession. Agric. Ecosyst. Environ. 2016, 223, 223-238. [CrossRef]

2. Crews, T.; Rumsey, B. What agriculture can learn from native ecosystems in building soil organic matter: A review. Sustainability 2017, 9, 578. [CrossRef]

3. Glover, J.D.; Culman, S.W.; DuPont, S.T.; Broussard, W.; Young, L.; Mangan, M.E.; Mai, J.G.; Crews, T.E.; DeHaan, L.R.; Buckley, D.H. Harvested perennial grasslands provide ecological benchmarks for agricultural sustainability. Agric. Ecosyst. Environ. 2010, 137, 3-12. [CrossRef]

4. Kell, D.B. Breeding crop plants with deep roots: Their role in sustainable carbon, nutrient and water sequestration. Ann. Bot. 2011, 108, 407-418. [CrossRef] [PubMed]

5. Gomiero, T. Soil degradation, land scarcity and food security: Reviewing a complex challenge. Sustainability 2016, 8, 281. [CrossRef]

6. Glover, J.D.; Reganold, J.P.; Bell, L.W.; Borevitz, J.; Brummer, E.C.; Buckler, E.S.; Cox, C.M.; Cox, T.S.; Crews, T.E.; Culman, S.W.; et al. Increased food and ecosystem security via perennial grains. Science 2010, 328, 1638-1639. [CrossRef] [PubMed]

7. Cox, S.; Nabukalu, P.; Paterson, A.; Kong, W.; Nakasagga, S. Development of perennial grain sorghum. Sustainability 2018, 10, 172. [CrossRef]

8. Zhang, S.; Hu, J.; Yang, C.; Liu, H.; Yang, F.; Zhou, J.; Samson, B.K.; Boualaphanh, C.; Huang, L.; Huang, G.; et al. Genotype by environment interactions for grain yield of perennial rice derivatives (Oryza sativa L./Oryza longistaminata) in southern China and Laos. Field Crops Res. 2017, 207, 62-70. [CrossRef]

9. DeHaan, L.R.; Van Tassel, D.L.; Anderson, J.A.; Asselin, S.R.; Barnes, R.; Baute, G.J.; Cattani, D.J.; Culman, S.W.; Dorn, K.M.; Hulke, B.S.; et al. A pipeline strategy for grain crop domestication. Crop Sci. 2016, 56, 917-930. [CrossRef] 
10. Jaikumar, N.S.; Snapp, S.S.; Murphy, K.; Jones, S.S. Agronomic assessment of perennial wheat and perennial rye as cereal crops. Agron. J. 2012, 104, 1716. [CrossRef]

11. Doebley, J.F.; Gaut, B.S.; Smith, B.D. The molecular genetics of crop domestication. Cell 2006, 127, $1309-1321$. [CrossRef] [PubMed]

12. Johnston, P.A.; Timmerman-Vaughan, G.M.; Farnden, K.J.F.; Pickering, R. Marker development and characterisation of Hordeum bulbosum introgression lines: A resource for barley improvement. Theor. Appl. Genet. 2009, 118, 1429-1437. [CrossRef] [PubMed]

13. Blattner, F.R. Progress in phylogenetic analysis and a new infrageneric classification of the barley genus Hordeum (Poaceae: Triticeae). Breed. Sci. 2009, 59, 471-480. [CrossRef]

14. von Bothmer, R.; Jacobsen, N.; Baden, C.; Jørgensen, R.B.; Linde-Laursen, I. An Ecogeographical Study of the Genus Hordeum, 2nd ed.; Systematic and ecogeographic studies on crop genepools 7; International Plant Genetic Resources Institute: Rome, Italy, 1995.

15. Blattner, F.R.; Pleines, T.; Jakob, S.S. Rapid radiation in the barley genus Hordeum (poaceae) during the pleistocene in the americas. In Evolution in Action: Case Studies in Adaptive Radiation, Speciation and the Origin of Biodiversity; Glaubrecht, M., Ed.; Springer: Berlin/Heidelberg, Germany, 2010; pp. 17-33.

16. von Bothmer, R.; Jacobsen, N. Interspecific crosses in Hordeum (Poaceae). Plant Syst. Evol. 1986, 153, 49-64. [CrossRef]

17. Walther, U.; Rapke, H.; Proeseler, G.; Szigat, G. Hordeum bulbosum-a new source of disease resistance-transfer of resistance to leaf rust and mosaic viruses from H. bulbosum into winter barley. Plant Breed. 2000, 119, 215-218. [CrossRef]

18. Toubia-Rahme, H.; Johnston, P.A.; Pickering, R.A.; Steffenson, B.J.; Graner, A. Inheritance and chromosomal location of Septoria passerinii resistance introgressed from Hordeum bulbosum into Hordeum vulgare. Plant Breed. 2003, 122, 405-409. [CrossRef]

19. Fetch, T.; Johnston, P.A.; Pickering, R. Chromosomal location and inheritance of stem rust resistance transferred from Hordeum bulbosum into cultivated barley (H. vulgare). Phytopathology 2009, 99, 339-343. [CrossRef] [PubMed]

20. Brassac, J.; Blattner, F.R. Species-level phylogeny and polyploid relationships in Hordeum (poaceae) inferred by next-generation sequencing and in silico cloning of multiple nuclear loci. Syst. Biol. 2015, 64, 792-808. [CrossRef] [PubMed]

21. Jakob, S.S.; Meister, A.; Blattner, F.R. The considerable genome size variation of Hordeum species (poaceae) is linked to phylogeny, life form, ecology, and speciation rates. Mol. Biol. Evol. 2004, 21, 860-869. [CrossRef] [PubMed]

22. von Bothmer, R.; Komatsuda, T. Barley origin and related species. In Barley; Ullrich, S.E., Ed.; Wiley-Blackwell: Chichester, UK, 2011; pp. 14-62.

23. Kakeda, K.; Ibuki, T.; Suzuki, J.; Tadano, H.; Kurita, Y.; Hanai, Y.; Kowyama, Y. Molecular and genetic characterization of the s locus in Hordeum bulbosum L., a wild self-incompatible species related to cultivated barley. Mol. Genet. Genomics 2008, 280, 509-519. [CrossRef] [PubMed]

24. Wang, C.M.; Xia, Z.R.; Wu, G.Q.; Yuan, H.J.; Wang, X.R.; Li, J.H.; Tian, F.P.; Zhang, Q.; Zhu, X.Q.; He, J.J.; et al. The coordinated regulation of $\mathrm{Na}(+)$ and $\mathrm{K}(+)$ in Hordeum brevisubulatum responding to time of salt stress. Plant Sci. 2016, 252, 358-366. [CrossRef] [PubMed]

25. Garthwaite, A.J.; von Bothmer, R.; Colmer, T.D. Salt tolerance in wild Hordeum species is associated with restricted entry of $\mathrm{Na}^{+}$and $\mathrm{Cl}^{-}$into the shoots. J. Exp. Bot. 2005, 56, 2365-2378. [CrossRef] [PubMed]

26. Kosová, K.; Vítámvás, P.; Prášil, I.T. Wheat and barley dehydrins under cold, drought, and salinity-What can LEA-II proteins tell us about plant stress response? Front. Plant Sci. 2014, 5. [CrossRef] [PubMed]

27. Liu, B.; Sun, G. Micrornas contribute to enhanced salt adaptation of the autopolyploid Hordeum bulbosum compared with its diploid ancestor. Plant J. 2017, 91, 57-69. [CrossRef] [PubMed]

28. Aliyeva-Schnorr, L.; Stein, N.; Houben, A. Collinearity of homoeologous group 3 chromosomes in the genus Hordeum and Secale cereale as revealed by 3H-derived FISH analysis. Chromosome Res. 2016, 24, 231-242. [CrossRef] [PubMed]

29. Mascher, M.; Richmond, T.A.; Gerhardt, D.J.; Himmelbach, A.; Clissold, L.; Sampath, D.; Ayling, S.; Steuernagel, B.; Pfeifer, M.; D'ascenzo, M. Barley whole exome capture: A tool for genomic research in the genus Hordeum and beyond. Plant J. 2013, 76, 494-505. [CrossRef] [PubMed] 
30. Wendler, N.; Mascher, M.; Himmelbach, A.; Bini, F.; Kumlehn, J.; Stein, N. A high-density, sequence-enriched genetic map of Hordeum bulbosum and its collinearity to H. vulgare. Plant Genome 2017, 10. [CrossRef] [PubMed]

31. Pickering, R. The production of fertile triploid hybrids from crosses between Hordeum vulgare L. $(2 n=4 x=28)$ and H. bulbosum L. $(2 \mathrm{n}=2 \mathrm{x}=14)$. Hereditas 1991, 114, 227-236. [CrossRef] 